\title{
Use of silver nanoparticles increased inhibition of cell-associated HIV-1 infection by neutralizing antibodies developed against HIV-1 envelope proteins
}

\author{
Humberto H Lara', Liliana Ixtepan-Turrent ${ }^{2}$, Elsa N Garza Treviño ${ }^{2}$ and Dinesh K Singh ${ }^{1 *}$
}

\begin{abstract}
Background: HIV/AIDS pandemic is a worldwide public health issue. There is a need for new approaches to develop new antiviral compounds or other therapeutic strategies to limit viral transmission. The envelope glycoproteins gp120 and gp41 of HIV are the main targets for both silver nanoparticles (AgNPs) and neutralizing antibodies. There is an urgency to optimize the efficiency of the neutralizing antibodies (NABs). In this study, we demonstrated that there is an additive effect between the four NABs and AgNPs when combined against cellassociated HIV-1 infection in vitro

Results: Four NABs (Monoclonal antibody to HIV-1 gp41 126-7, HIV-1 gp120 Antiserum PB1 Sub 2, HIV-1 gp120 Antiserum PB1, HIV-1 gp120 Monoclonal Antibody F425 B4e8) with or without AgNPs of 30-50 nm in size were tested against cell free and cell-associated HIV ${ }_{\text {IIIB }}$ virus. All NABs inhibited HIV-1 cell free infection at a dose response manner, but with AgNPs an antiviral additive effect was not achieved Although there was no inhibition of infection with cellassociated virus by the NABs itself, AgNPs alone were able to inhibit cell associated virus infection and more importantly, when mixed together with NABs they inhibited the HIV-1 cell associated infection in an additive manner.
\end{abstract}

Discussion: The most attractive strategies to deal with the HIV problem are the development of a prophylactic vaccine and the development of effective topical vaginal microbicide. For two decades a potent vaccine that inhibits transmission of infection of HIV has been searched. There are vaccines that elicit NABs but none of them has the efficacy to stop transmission of HIV-1 infection. We propose that with the addition of AgNPs, NABs will have an additive effect and become more potent to inhibit cell-associated HIV-1 transmission/infection.

Conclusions: The addition of AgNPs to NABs has significantly increased the neutralizing potency of NABs in prevention of cell-associated HIV-1 transmission/infection. Further exploration is required to standardize potentiation of NABs by AgNPs. It is also required to evaluate in vivo toxicity of AgNPs before AgNPs could be incorporated in any antiviral vaginal creams.

Keywords: Silver Nanoparticles, Neutralizing Antibodies, HIV, gp120, gp41

\section{Introduction}

The pandemic of Acquired Immunodeficiency Syndrome (AIDS), caused by the Human Immunodeficiency Virus Type 1 (HIV-1) infection, is a worldwide public health issue [1]. The latest estimates by the Joint United

\footnotetext{
* Correspondence: singhd@wssu.edu

'Department of Life Sciences, Winston-Salem State University, Winston Salem, NC, 27110, USA

Full list of author information is available at the end of the article
}

Nations Program on HIV/AIDS (UNAIDS) indicate that more than 33.3 million people worldwide are living with HIV-1 infection or AIDS.

The medical use of the cocktail drugs known as highly active antiretroviral therapies (HAART) has significantly reduced morbidity and mortality among AIDS patients $[2,3]$. Unfortunately, the achievement of HAART is insufficient and compromised by the evolution of drug resistance HIV strains [4]. Consequently, the search for

\section{() Biomed Central}


new therapies to inhibit viral infection or to restore the damaged immune system in HIV/AIDS patients continues. Newly discovered drugs are constantly evaluated as therapeutic drug candidates. These new drugs are eagerly awaited for the growing number of HIV-infected individuals who have developed resistance to the currently existing antiretrovirals [5].

The most attractive strategies to deal with the HIV problem are the development of a prophylactic vaccine and the development of an effective topical vaginal and rectal microbicides. Both approaches are essential and eventually a combination of the two may prove to be most effective strategy in controlling the HIV-1 epidemic by diminishing the incidence of human-to-human transmission events [6].

The discovery of an HIV-1 vaccine that elicits broadly efficient neutralizing antibodies still remains an elusive goal especially after the recent failure of the leading $\mathrm{T}$ cell based HIV vaccine in human efficacy trials [7]. The envelope glycoproteins gp120 and gp41 that are the main targets for neutralizing antibodies are partially shielded by N-linkedglycans and other structurallyimposed steric constraints that limit antibody access to potential neutralization epitopes. The complex level of antigenic diversity of HIV-1, the shielding of key epitopes within the three dimensional structure of the native Env trimer, and the failure of newer versions of Env proteins to elicit broadly reactive antibodies have led to some pessimism regarding the potential to ever elicit high titers of neutralizing antibodies against diverse strains of HIV-1. Therefore there is a need to maximize the efficiency of whatever titers of neutralizing antibodies generated by vaccines [8].

A significant correlation is usually reported linking the ability of an antibody to neutralize HIV-1 in vitro and to protect in vivo against HIV-1 in animal models. Some vaccine research studies have measured the capability of specific NABs to protect against SHIV infection, and found that efficient immunity is achieved only when the serum concentration of NABs in the challenged animals is many multiples of the in vitro neutralization titer. Normally these NABs require relatively high antibody concentrations that may be highly difficult to reach by vaccination [9].

Silver ions in complexes or compounds have been used for centuries to disinfect fluids, solids and tissues [10]. There is no cross resistance with antibiotics [11] and probably there is also no induction of antimicrobial resistance by silver ions [12]. The Crede's solution (silver nitrate $0.2 \%$ ) has been used to prevent the Neonatal conjunctivitis ("ophtalmia neonatorum") which is a form of bacterial conjunctivitis contracted during delivery. The eyes are infected during passage through the birth canal from a mother infected with either Neisseria gonorrhoeae or Chlamydia trachomatis. Crede's solution was used to prevent the condition. If left untreated it could cause blindness [13]. Also Silver sulfadiazine is widely used by physicians to treat severe burns in skin, this topical cream not only acts against infections, but also against inflammation and enhance the healing of the tissue. The many attempts to find a better remedy for the topical treatment of burns than silver sulphadiazine have so far been without success [14].

Recent advances in nanotechnology have enabled the scientific community to investigate and manipulate materials at nanometer level. Nano-based delivery systems can be adapted to modulate drug release, reduce drug-associated toxicity, protect drugs from metabolism, and target drugs to affected cells, tissues, and compartments [15-19]. Nowadays we can use pure silver of nanometer sizes. We previously reported that AgNPs inhibit HIV -1 and that these nanoparticles attach to the gp120 [20]. Then we investigated the mode of antiviral action, with a panel of tests we probed that AgNPs:- a) attach to the envelope of the HIV-1 inhibiting the interaction with CD4 receptor,:-b) inhibits a wide range of HIV-1 regardless of the tropism,:-c) inhibit entry and fusion of the virus to the target cell at a non-toxic range. AgNPs proved to be more efficient than silver ions at non-cytotoxic levels [21].

With the above antiviral characteristics, AgNPs are appealing to be included as an active compound in a vaginal topical gel. We previously demonstrated that Polyvinylpyrrolidone (PVP) AgNPs mixed in a topical gel, inhibit the transmission of infection when applied to the human cervical tissue in a model for explants, at a non-toxic range, and more significantly, AgNPs acts rapidly in less than a minute and protect the human cervical tissue for more than 48 hours even after an extensive wash of the gel, without any toxicity to the human cervical explants [22].

In the present study we decided to investigate the additive effect of AgNPs with four NABs (Monoclonal antibody to HIV-1 gp41 126-7 [23], HIV-1 gp120 Antiserum PB1 Sub 2, HIV-1 gp120 Antiserum PB1 [24-26], HIV-1 gp120 Monoclonal Antibody F425 B4e8 [27]) as both act against viral envelope glycoprotein trimers on the surface of the virus that mediate receptor binding and entry.

\section{Results}

Inhibition of cell free HIV $_{\text {IIIB }}$ virus infection by Monoclonal antibody to HIV-1 gp41 (126-7) and Silver Nanoparticles in U373-MAGI-CXCR4 $4_{\text {CEM }}$ cells

In this experiment, we evaluated inhibition of cell free HIV-1 $1_{\text {IIIB }}$ virus infection by monoclonal antibody to HIV-1 gp41 (126-7) in U373-MAGI-CXCR4 $4_{\text {CEM }}$ cells. The toxic dose of $1 \mathrm{mg} / \mathrm{ml} \mathrm{AgNPs}$ was ascertained on a 
cytotoxicity assay and was found to be $28 \%$ (data not shown). The AgNPs alone showed 40\% inhibition of cell free HIV-1 $1_{\text {IIIB }}$ virus infection at this concentration against a control (virus infection wihout AgNPs). The monoclonal antibody to HIV-1 gp41 (126-7) alone showed ability to inhibit infection (16-25\%) of HIV-1 $1_{\text {IIIB }}$ in a dose response manner. The different dilutions of $\mathrm{NAB}$, when added with AgNPs at $1 \mathrm{mg} / \mathrm{mL}$, increased HIV-1 ${ }_{\text {IIIB }}$ inhibition by $47-63 \%(\mathrm{P}<0.002)$ until the NAB dilution of 1:160. There was no additive effect observed.(Figure 1).

Inhibition of cell free HIV $_{\text {IIIB }}$ virus infection by HIV-1 gp120 Antiserum (PB1) and Silver Nanoparticles in U373MAGI-CXCR4 ${ }_{\text {CEM }}$ cells

The HIV-1 gp120 Antiserum (PB1) alone showed inhibition of HIV-1 ІІІв infection in a dose response manner

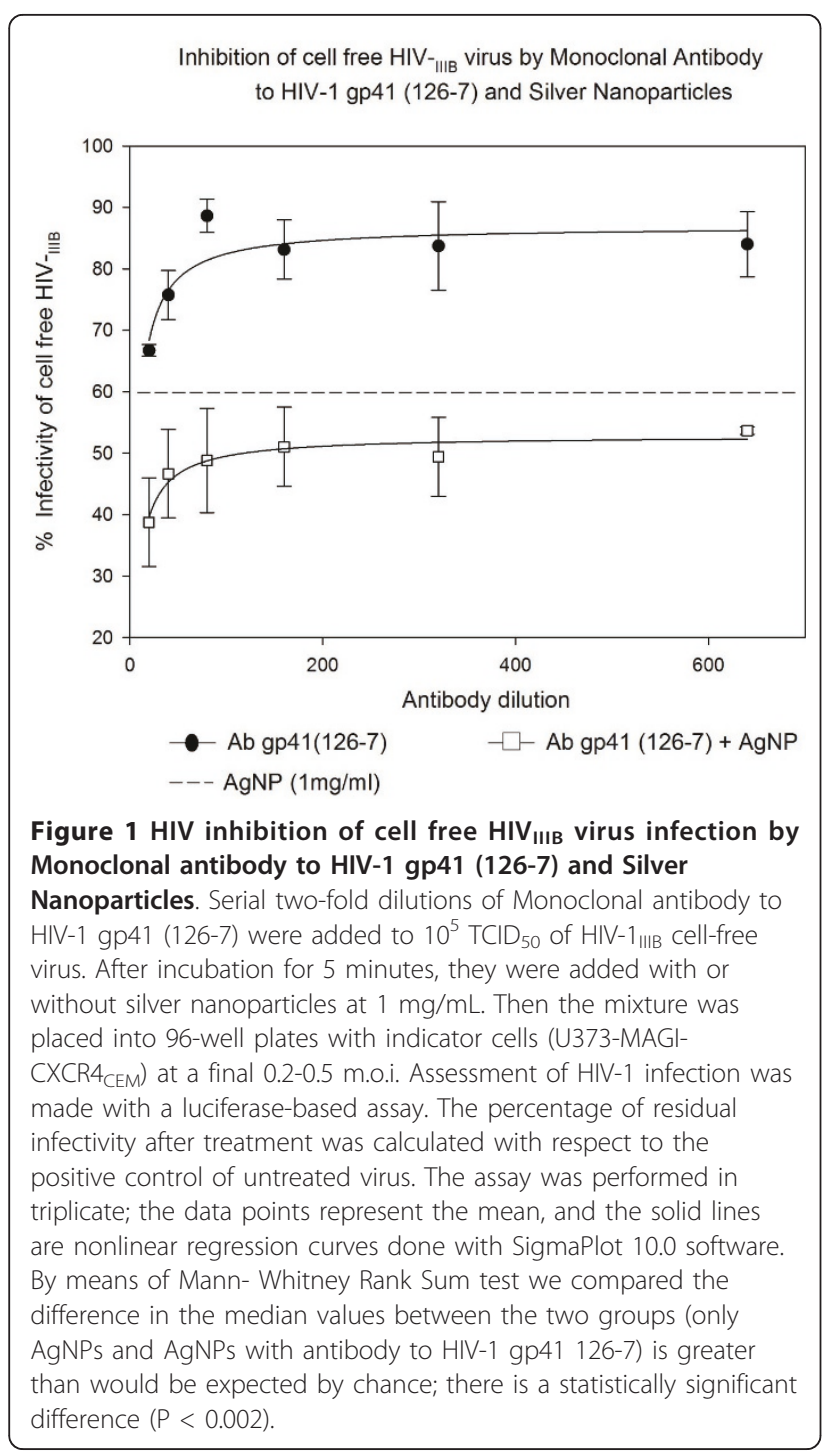

(10-30\%). The addition of AgNPs at $1 \mathrm{mg} / \mathrm{mL}$ showed no effect in this experiment. The HIV-1 gp120 Antiserum (PB1) dilutions 1:20 and 1:40 showed mild inhibition alone when compared to the inhibition by the mixture of AgNPs and NABs (47 and 41\% inhibition, P $<0.065)$. After that dilution inhibition of HIV-1 ІІІв virus decreased and was less than AgNPs alone 40\%, (Figure 2). Inhibition of cell free HIV $_{\text {IIIB }}$ virus infection by HIV-1
gp120 Antiserum (PB1 Sub 2) and Silver Nanoparticles in
U373-MAGI-CXCR4 $4_{\text {CEM Cells }}$
The HIV-1 gp120 Antiserum (PB1 sub 2) alone was found to have the best ability to inhibit infection of HIV-1 $1_{\text {IIIв }}(18-71 \%)$ in a dose response manner compared to other three NABs. When added with AgNPs at $1 \mathrm{mg} / \mathrm{mL}$, an increase of inhibitory effect was observed until the NAB dilution of 1:640. The addition of AgNPs

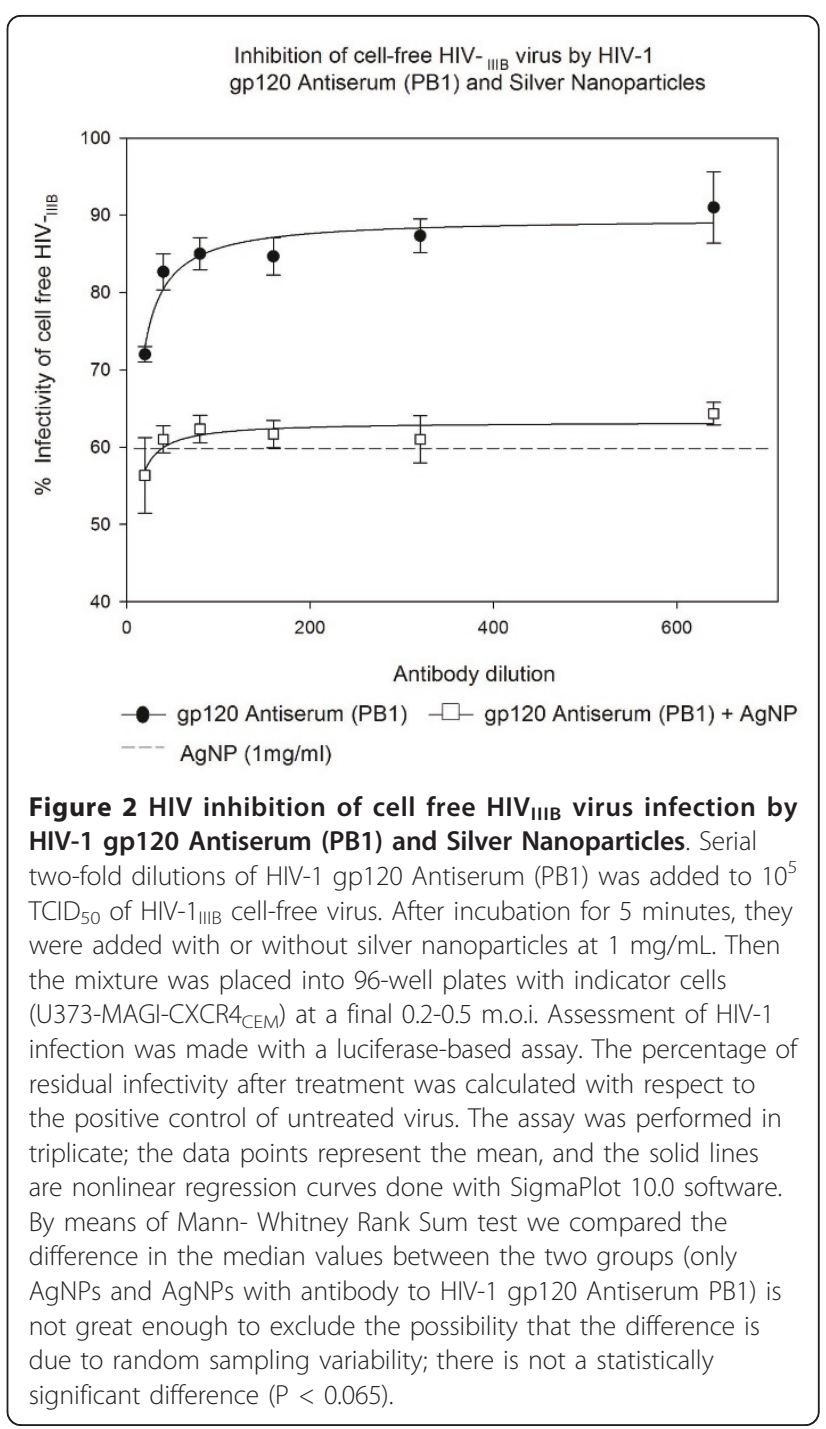


increased HIV-1 $1_{\text {IIIB }}$ inhibition $(42-72 \%, \mathrm{P}<0.008)$. there was no additive effect. (Figure 3).

Inhibition of cell free HIV $_{\text {IIIB }}$ virus infection by HIV-1 gp120 Monoclonal Antibody (F425 B4e8) and Silver Nanoparticles in U373-MAGI-CXCR4 ${ }_{\text {CEM }}$ cells

The HIV-1 gp120 Monoclonal Antibody (F425 B4e8) was found to mildly inhibit infection of HIV-1 $1_{\text {IIIB }}$ in a dose response manner (5-11\%). When added with AgNPs at $1 \mathrm{mg} / \mathrm{mL}$ no effect was observed. The use of AgNPs along with HIV-1 gp120 Monoclonal Antibody (F425 B4e8) showed inhibition efficacy of NAB 36-40\% $(\mathrm{P}<0.008)$ which was less than AgNPs alone (Figure 4).

Inhibition of cell associated HIV $_{\text {IIIB/H9 }}$ virus infection by Monoclonal antibody to HIV-1 gp41 (126-7), and Silver Nanoparticles in U373-MAGI-CXCR4 ${ }_{\text {CEM }}$ cells

The monoclonal antibody to HIV-1 gp41 (126-7) itself has very little effect (6-10\% inhibition) on cell associated HIV-1 $1_{\text {IIIB/H9 }}$ virus infection. The AgNPs however

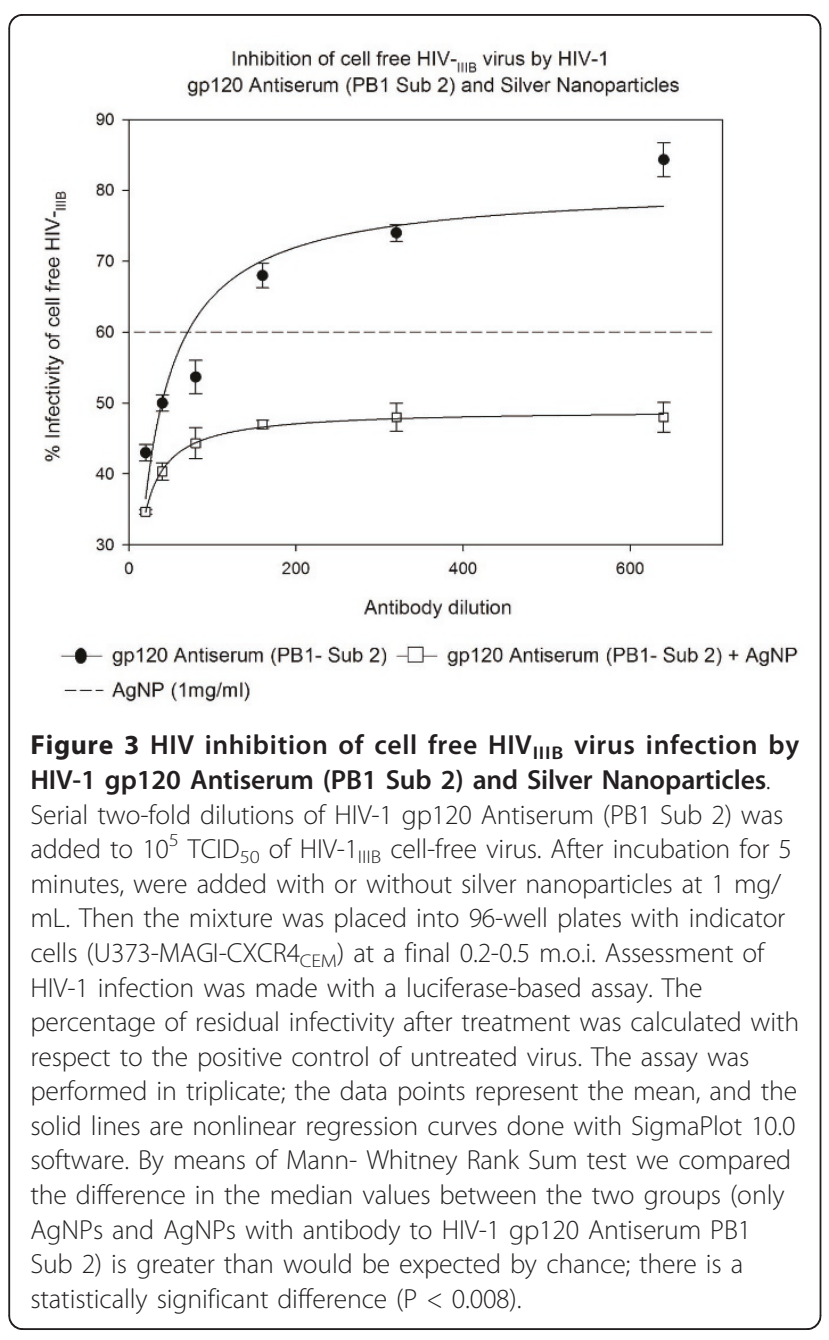

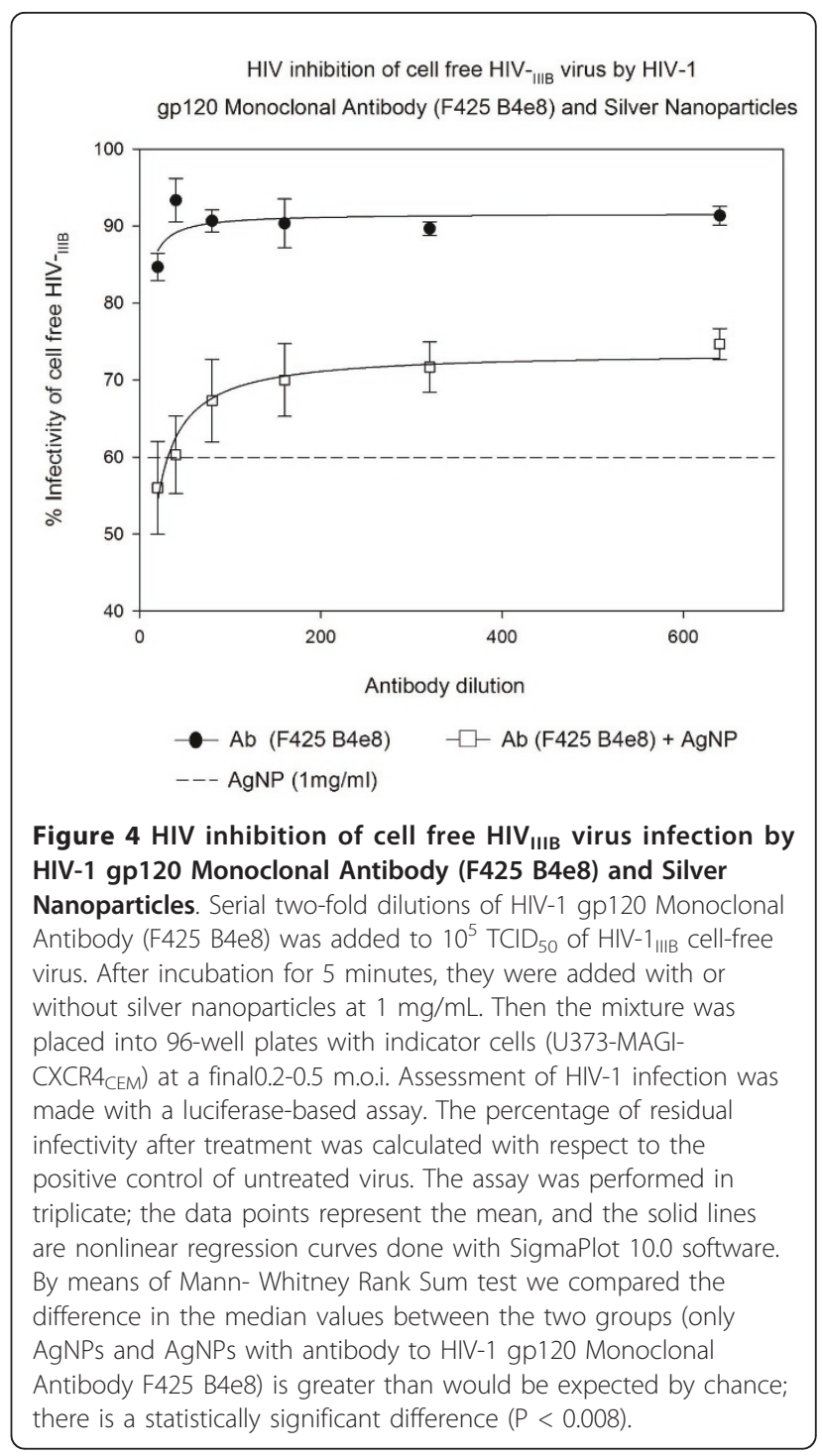

showed inhibition of $\mathrm{HIV}-1_{\mathrm{IIIB} / \mathrm{H} 9}$ virus infection $(50 \%)$ at $1 \mathrm{mg} / \mathrm{mL}$ concentration. The monoclonal antibody to HIV-1 gp41 (126-7) when added with AgNPs showed additive effect till 1:640 dilutions, increasing inhibition of $\mathrm{HIV}-1_{\text {IIIB/H9 }}$ virus to $62-71 \%(\mathrm{P}<0.002)$. This inhibitory effect was however lost after 1:640 dilution of $\mathrm{NAB}$ and only the inhibition of AgNPs alone were observed (Figure 5).

Inhibition of cell associated HIV $_{\text {IIIB/H9 }}$ virus infection by HIV-1 gp120 Antiserum (PB1) and Silver Nanoparticles in U373-MAGI-CXCR4 ${ }_{\text {CEM }}$ cells

The HIV-1 gp120 Antiserum (PB1) showed 3-12\% inhibitory effect on cell associated HIV-1 $1_{\text {IIIB/H9 }}$ virus, addition of AgNPs at $1 \mathrm{mg} / \mathrm{mL}$ increased inhibition of virus (60-68\% inhibition, $\mathrm{P}<0.002$ ) suggesting a strong additive effect of AgNPs on HIV-1 gp120 Antiserum-PB1(Figure 6). 


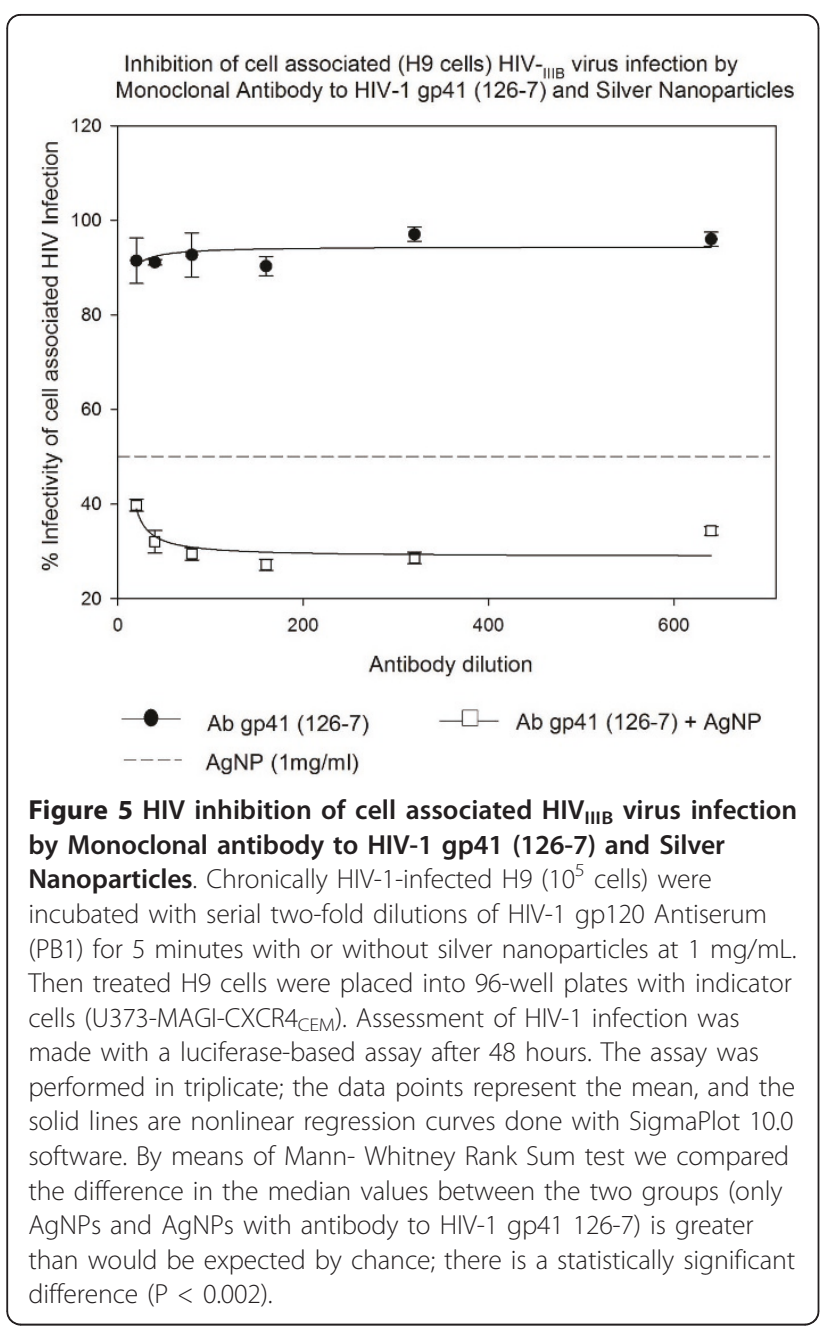

Inhibition of cell associated $\mathrm{HIV}_{\mathrm{IIIB} / \mathrm{H} 9}$ virus infection by HIV-1 gp120 Antiserum (PB1 Sub 2) and Silver Nanoparticles in U373-MAGI-CXCR4 $4_{\text {CEM }}$ cells

The HIV-1 gp120 Antiserum (PB1 sub 2) alone showed $3-12 \%$ inhibition of cell associated $\mathrm{HIV}-1_{\mathrm{III} / \mathrm{H} 9}$ virus infection in a dose response manner. This inhibition was increased to $61-69 \%$ inhibition $(\mathrm{P}<0.002)$ when added with AgNPs at $1 \mathrm{mg} / \mathrm{mL}$ concentration indicating an additive effect between AgNPs and HIV-1 gp120 Antiserum-PB1 Sub 2 (Figure 7).

Inhibition of cell associated HIV $_{\text {IIIB/H9 }}$ virus infection by HIV-1 gp120 Monoclonal Antibody (F425 B4e8) and Silver Nanoparticles in U373-MAGI-CXCR4 $4_{\text {CEM }}$ cells

The HIV-1 gp120 Monoclonal Antibody (F425 B4e8) alone showed 1-9\% inhibition of cell associated HIV$1_{\mathrm{IIIB} / \mathrm{H} 9}$ virus infection in a dose response manner. Addition of AgNPs at $1 \mathrm{mg} / \mathrm{mL}$ concentration resulted in significant increase $(\mathrm{P}<0.002)$ in the inhibitory effect of this cocktail signifying an additive effect between AgNPs

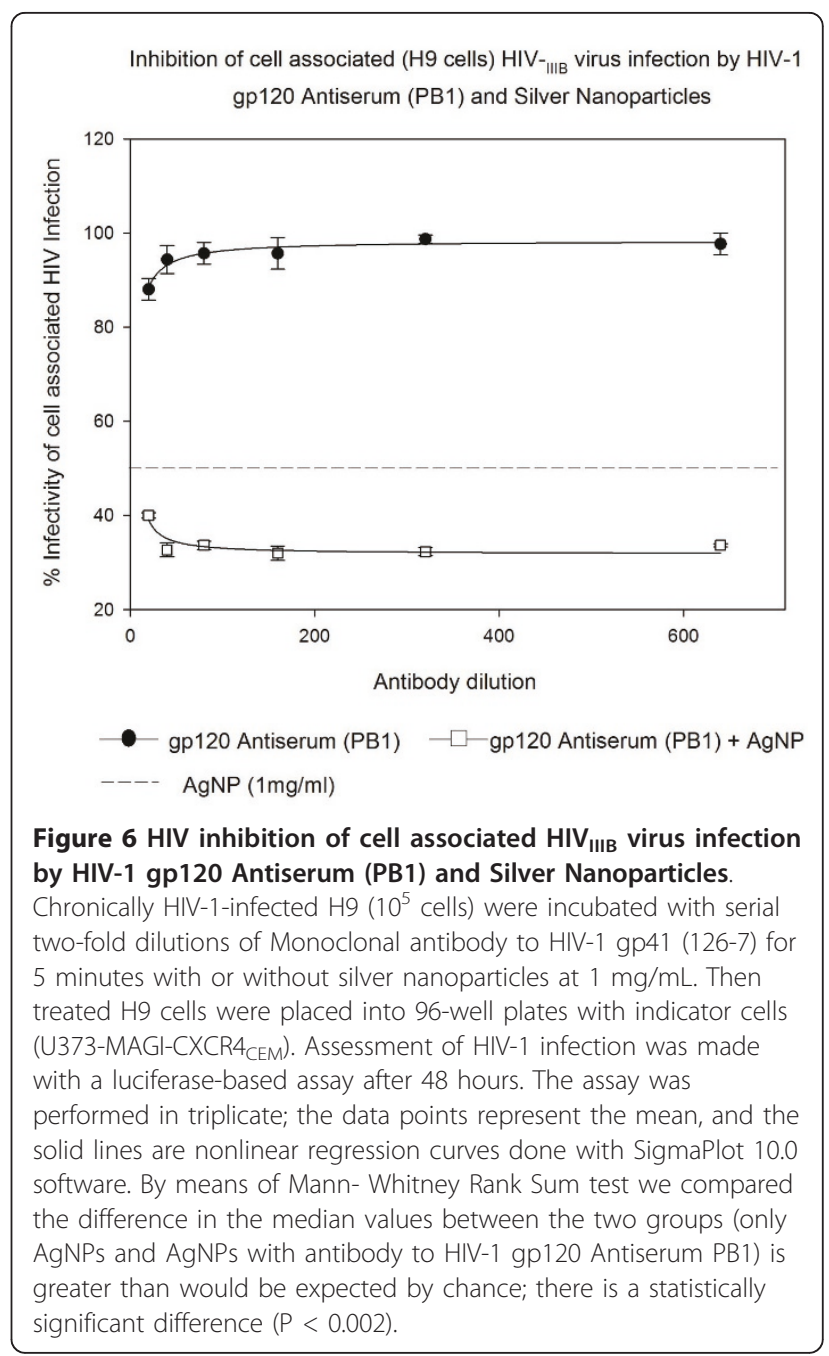

and HIV-1 gp120 Monoclonal Antibody (F425 B4e8). The inhibition of cell associated HIV-1 $1_{\mathrm{IIIB} / \mathrm{H} 9}$ virus infection increased to $58-60 \%$ (Figure 8 ).

\section{Discussion}

Vaccine-induced neutralizing antibodies that inhibit viral entry or fusion to the target cell are the protective correlates of most existing HIV vaccines [[8,9] and [23]]. Nevertheless, for highly variable viruses such as HIV-1, the ability to elicit broadly neutralizing antibody responses through vaccination has proven to be extremely difficult.

The major targets for HIV-1 NABs are the viral envelope glycoprotein trimers on the surface of the virus that mediate receptor binding and entry [24,27]. HIV-1 has evolved many mechanisms on the surface of envelope glyco-proteins to evade antibody-mediated neutralization, including the masking of conserved regions by glycan, quaternary protein interactions and the presence of immunodominant variable elements. In our previous 


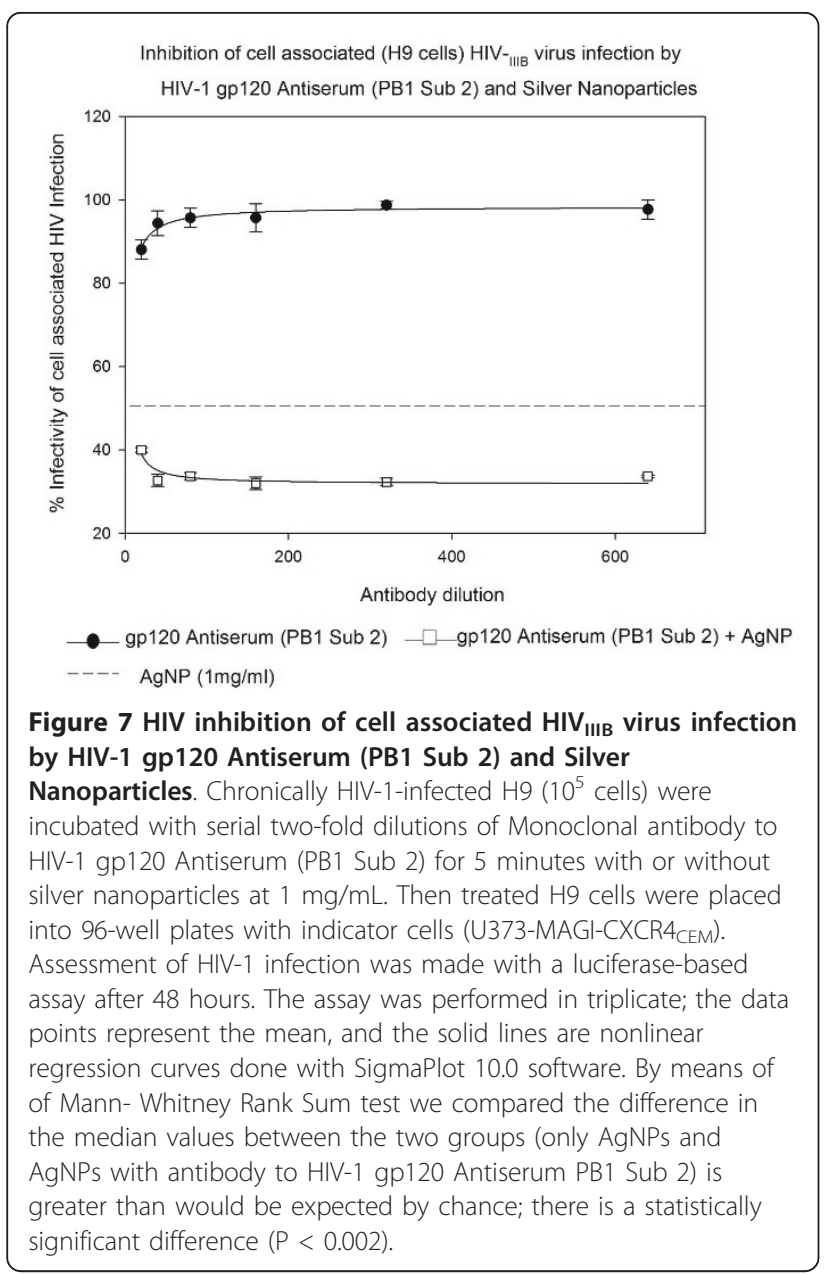

studies we have demonstrated that silver nanoparticles also bind to gp120 and gp41 part of HIV-1 envelop to inhibit HIV-1 infectivity [21,22].

The silver nanoparticles and NABs both use epitopes on the HIV-1 envelope glycoproteins as their binding targets. It was important to study if they could increase HIV-1 inhibition when used together. In our previous studies, we had reported toxicity and dose dependent inhibition of HIV-1 $1_{\text {IIIB }}$ by silver nanoparticles $[21,22]$. In the present study, we have used most effective but least toxic concentration of silver nanoparticles [21] to evaluate its effect on neutralizing ability of four NABs against cell free HIV-1 $1_{\text {IIIB }}$ and cell associated $\mathrm{HIV}-1_{\mathrm{IIIB} / \mathrm{H} 9}$ virus in U373-MAGI-CXCR4 $4_{\text {CEM }}$ cells. In the first experiment, we evaluated inhibition of cell free HIV-1 $1_{\text {IIIB }}$ virus infection by monoclonal antibody to HIV-1 gp41 (1267), HIV-1 gp120 antiserum (PB1), HIV-1 gp120 antiserum (PB1 sub 2), HIV-1 gp120 monoclonal antibody (F425B4e8), and compared that with HIV-1 inhibition by AgNPs alone and relevant NABs + AgNPs cocktail. Out of four NABs used, the HIV-1 gp120 antiserum (PB1 sub 2) was most potent NAB (neutralizing
Inhibition of cell associated (H9 cells) HIV- ${ }_{\text {IIIB }}$ virus infection by HIV-1 gp120 Monoclonal Antibody (F425 B4e8) and Silver Nanoparticles

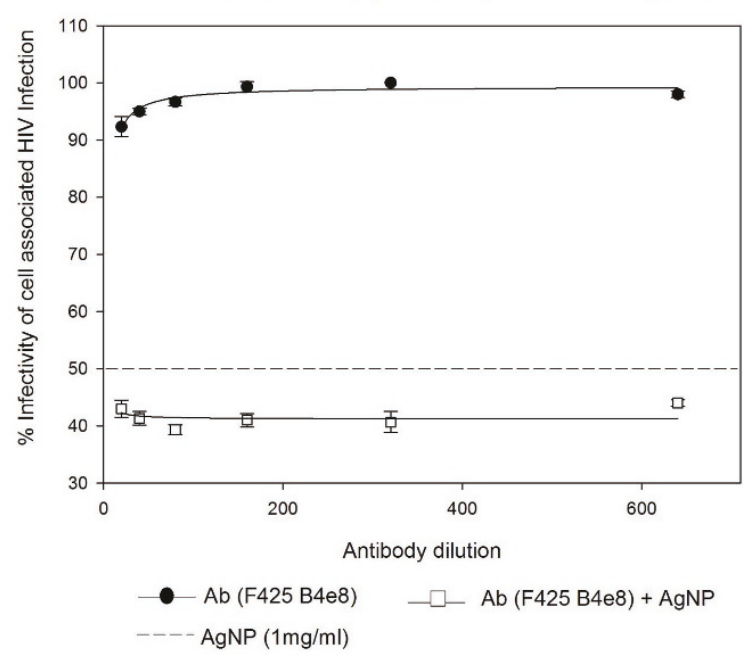

Figure 8 HIV inhibition of cell associated HIV $\mathrm{IIIB}_{\text {B }}$ virus infection by HIV-1 gp120 Monoclonal Antibody (F425 B4e8) and Silver Nanoparticles. Chronically HIV-1-infected H9 $\left(10^{5}\right.$ cells) were incubated with serial two-fold dilutions of HIV-1 gp120 Monoclonal Antibody (F425 B4e8) for 5 minutes with or without silver nanoparticles at $1 \mathrm{mg} / \mathrm{mL}$. Then treated $\mathrm{H} 9$ cells were placed into 96-well plates with indicator cells (U373-MAGI-CXCR4 $4_{\text {CEM }}$ ).

Assessment of HIV-1 infection was made with a luciferase-based assay after 48 hours. The assay was performed in triplicate; the data points represent the mean, and the solid lines are nonlinear regression curves done with SigmaPlot 10.0 software. By means of Mann- Whitney Rank Sum test we compared the difference in the median values between the two groups (only AgNPs and AgNPs with antibody to HIV-1 gp120 Monoclonal Antibody F425 B4e8) is greater than would be expected by chance; there is a statistically significant difference $(P<0.002)$.

antibody) in inhibition of HIV-1 $1_{\text {IIIB }}$. It was expected as this antibody has been raised against HIV-1 $1_{\text {IIIB }}$ virus. Other three heterologous NABs were found to have varying degrees of $\mathrm{HIV}-1_{\text {IIIB }}$ inhibitory potencies. AgNPs at $1 \mathrm{mg} / \mathrm{ml}$ concentration have been shown to exert $\sim 40 \%$ inhibition of cell free HIV-1 $1_{\text {IIIB }}$ virus infection. When NABs and AgNPs were used together, we recorded no additive effect of inhibition of cell free HIV-1 $1_{\text {IIIB }}$ Virus infection.

Inhibition of cell -associated virus infection has been found difficult to achieve by the NABs alone. A few NABs when used at high titers were able to inhibit cell associated homologous virus. We attempted to record if AgNPs will be able to increase inhibition of cell associated virus by homologous and heterologous NABs. Since cell free and cell associated both viruses are present in the infectious inoculums in real life, any increase in inhibitory potencies of NABs against $\mathrm{HIV}-1_{\mathrm{IIIB} / \mathrm{H} 9}$ virus infection will be interesting. In our experiments, we have used all four NABs, described earlier, to 
evaluate their inhibitory effect on $\mathrm{HIV}-1_{\mathrm{IIIB} / \mathrm{H} 9}$ virus infection along with AgNPs. The NABs used in this set of experiments alone did not show significant inhibition (2-10\% inhibition) of cell- associated virus $\mathrm{HIV}-1_{\mathrm{IIIB} / \mathrm{H} 9}$ in U373-MAGI-CXCR4 ${ }_{\text {CEM }}$ cells. The AgNPs alone however were successful in inhibiting cell associated $\mathrm{HIV}-1_{\mathrm{IIIB} / \mathrm{H} 9}$ virus infection. In fact AgNPs alone were more potent (50\% inhibition) with cell associated HIV$1_{\text {IIIB /H9 }}$ virus infection than cell free HIV-1 $1_{\text {IIIB }}$ virus infection (40\% inhibition). At present we do not know the exact reason behind increased inhibition of cell associated virus v/s cell free virus. We assume it may be due to better binding between cell associated virus and AgNPs. The use of AgNPs+ all four NABs cocktail, however, produced significant increase in inhibition of cell associated $\mathrm{HIV}-1_{\mathrm{IIIB} / \mathrm{H} 9}$ virus infection. The use of this cocktail resulted in 60 to $71 \%$ inhibition of cell associated virus infection. All four antibodies used in this experiment had almost similar increase in inhibition of HIV-1 $1_{\text {IIIB/H9 }}$ virus infection. It appears that AgNPs when present along with NABs were able to bind different epitopes on gp120 and/or gp41 which NABs alone did not bind and vice versa. The mechanism behind this additive effect in cell-associated infection is not known and needs further evaluation. Nevertheless, this is very significant finding because cell- associated viruses are the main source of HIV-1 transmission. Recently Diane and colleagues have shown that latently infected CD4+ $\mathrm{T}$ cells in breast milk from women with or without antiretroviral drugs simultaneously produce HIV-1 and increase chances of transmission between mothers to infant [28]. A similar phenomenon is expected with latently infected cells in semen and vaginal secretions. In this light, the additive inhibitory efficiency of AgNPs along with NABs against cell associated virus infection is a very positive data that suggests use of this strategy in developing antiviral vaginal gel/cream to prevent HIV-1 virus transmission.

\section{Conclusion}

The NABs have been shown to inhibit HIV-1 transmission of infection at very high titers in vitro. But the available vaccines under evaluation in various labs are unable to elicit such high titers in vivo, resulting in lowered efficacy and/or failure of vaccine against viral challenges. Silver nanoparticles used along with NABs against cell free HIV-1 $1_{\text {IIIB }}$ virus had no additive effect. In the case of cell associated HIV-1 $1_{\mathrm{IIIB} / \mathrm{H} 9}$ virus, all four NABs evaluated in this study showed almost no inhibitory effect by itself. Only AgNPs showed capability to inhibit cell- associated HIV-1 $1_{\mathrm{IIIB} / \mathrm{H} 9}$ virus. However, when used together, the results showed additive effect, increasing the inhibitory effect of AgNPs, and NABs cocktail in case of all four NABs used. The mechanism behind this increase in potency is not well understood and requires further study.

\section{Methods \\ Antibodies, cells and HIV-1 isolates}

The HIV-1 $1_{\text {IIIB }}$ virus alongwith the following reagents were obtained through the NIH AIDS Research and Reference Reagent Program, Division of AIDS, NIAID: U373-MAGI-CXCR4 ${ }_{\text {CEM }}$ from Dr. Michael Emerman, HTLV-III ${ }_{B}$ from Dr. Robert Gallo, Monoclonal antibody to HIV-1 gp41 (126-7) from Dr. Susan Zolla-Pazner, HIV-1 gp120 Antiserum (PB1 Sub 2), HIV-1 gp120 Antiserum (PB1), and HIV-1 gp120 Monoclonal Antibody (F425 B4e8) from Dr. Marshall Posner and Dr. Lisa Cavacini.

\section{Silver compounds}

Commercially manufactured $30-50 \mathrm{~nm}$ silver nanoparticles, surface coated with 0.2 wt\% PVP, were used (Nanoamor, Houston, TX). Stock solutions were prepared in RPMI 1640 cell culture media. The serial dilutions of the stock were made in culture media.

\section{Cytotoxicity Assay}

A stock solution of AgNPS was two-fold diluted to desired concentrations in growth medium and subsequently added into wells containing $5 \times 10^{4} \mathrm{U} 373$ MAGI-CXCR4 $4_{\text {CEM }}$ cells to a final volume of $100 \mu \mathrm{l}$. Microtiter plates were incubated at $37^{\circ} \mathrm{C}$ in a $5 \% \mathrm{CO}_{2}$ air humidified atmosphere for 24 hours. Assessments of cell viability were carried out using a CellTiter-Glo ${ }^{\circledR}$ Luminescent Cell Viability Assay and Glomax Multidirection System (Promega). Cytotoxicity was evaluated based on the percentage cell survival relative to the control in the absence of any compound [21].

\section{Range of antiviral activity of Neutralizing Antibodies (NABs) against HIVIIIB cell-free virus}

Serial two-fold dilutions of neutralizing antibodies: Monoclonal antibody to HIV-1 gp41 (126-7), HIV-1 gp120 Antiserum (PB1 Sub 2), HIV-1 gp120 Antiserum (PB1), and HIV-1 gp120 Monoclonal Antibody (F425 B4e8) or just media as control were added to HIV-1 $1_{\text {IIIB }}$ cell-free virus to a final volume of $50 \mu \mathrm{l}$. After incubation for $5 \mathrm{~min}$ at room temperature we added media with or without AgNPs $1 \mathrm{mg} / \mathrm{mL}$ and placed into 96well plates with U373-MAGI-CXCR4 $4_{\text {CEM }}$ cells to a final volume of $50 \mu \mathrm{l}$. The cells were incubated in a $5 \% \mathrm{CO}_{2}$ humidified incubator at $37^{\circ} \mathrm{C}$ for $24 \mathrm{~h}$. Assessment of HIV-1 infection was performed with the Beta-Glo Assay System using Glomax Multidirection System (Promega). The percentage of residual infectivity after NABs or media as control was calculated with respect to the control. The $50 \%$ inhibitory concentration $\left(\mathrm{IC}_{50}\right)$ was 
defined according to the percentage of infectivity inhibition relative to the positive control.

\section{Range of antiviral activity of Neutralizing Antibodies (NABs) against HIVIIIB cell-associated virus}

Serial two-fold dilutions of neutralizing antibodies: Monoclonal antibody to HIV-1 gp41 (126-7), HIV-1 gp120 Antiserum (PB1 Sub 2), HIV-1 gp120 Antiserum (PB1), and HIV-1 gp120 Monoclonal Antibody (F425 $\mathrm{B} 4 \mathrm{e} 8$ ) or just media as control were added to $\mathrm{H} 9$ cells $\left(5 \times 10^{4}\right.$ per well) chronically infected with $\mathrm{HIV}_{\text {IIIB }}$ to a final volume of $50 \mu \mathrm{l}$. After incubation for $5 \mathrm{~min}$ at room temperature we added media with or without AgNPs $1 \mathrm{mg} / \mathrm{mL}$ and placed into 96-well plates with U373-MAGI-CXCR4 $4_{\text {CEM }}$ cells to a final volume of $50 \mu \mathrm{l}$. The cells were incubated in a $5 \% \mathrm{CO}_{2}$ humidified incubator at $37^{\circ} \mathrm{C}$ for $24 \mathrm{~h}$. Assessment of HIV-1 infection was performed with the Beta-Glo Assay System. The percentage of residual infectivity after NABs or media as control was calculated with respect to the control. The $50 \%$ inhibitory concentration $\left(\mathrm{IC}_{50}\right)$ was defined according to the percentage of infectivity inhibition relative to the positive control.

\section{Statistical analysis}

Graphs were done with SigmaPlot 10.0 software and the values shown are means \pm standard deviations from three separate experiments, each of which was carried out in duplicate. Cytotoxicity and inhibition assessment graphs are linear regression curves done with SigmaPlot 10.0 software. Wilcoxon rank-sum (Wilcoxon-MannWhitney test) test was performed to compare the two groups of results (HIV-1 infectivity by AgNPs, and AgNPs mixed with NABs.

\section{List of Abbreviations}

AgNPs: Silver Nanoparticles; NABs: Neutralizing antibodies; gp120: HIV Envelop Glycoprotein 120 KD; gp41: HIV Enveloped Glycoprotein 41KD; $\mathrm{TCID}_{50}$ : Tissue Culture Infective Dose 50; PVP: Polyvinylpyrrolidone

\section{Acknowledgements \\ The project described was supported by Award Number P20MD002303 from the National Center on Minority Health and Health Disparities, and SC3GM084802 from National Institute of General Medical Sciences of NIH to DKS. The content is solely the responsibility of the authors and does not necessarily represent the official views of the National Center on Minority Health and Health Disparities or NIGMS or the National Institutes of Health. This research is a project supported by Winston-Salem State University's Center of Excellence for the Elimination of Health Disparities.}

\section{Author details}

'Department of Life Sciences, Winston-Salem State University, Winston Salem, NC, 27110, USA. ²Laboratorio de Terapia Celular, Departamento de Bioquimicay Medicina Molecular, Facultad de Medicina Universidad Autonoma de Nuevo Leon, Mexico.

\section{Authors' contributions}

All authors read and approved the final manuscript. HHL participated in the conception and experimental design and performed in vitro HIV-1 infectivity assays. He also participated in the analysis and interpretation of the data, and in writing this report. LIT participated in the conception and design of the in vitro HIV-1, in analysis and interpretation of the data, and in writing and revision of this report. ENG participated in in vitro HIV-1 infectivity assays. DKS participated in the experimental design of this research, editing and revision of this report. His lab provided materials and resources used in this study.

\section{Authors Information}

DKS: is an associate professor of microbiology at the Winston Salem State University. DKS' lab is working on development of a DNA vaccine for HIV/ AIDS. His other research interest involves prevention of HIV-1 transmission at the cervical/vaginal mucosal surfaces. His current research is funded by two $\mathrm{NIH}$ grants.

\section{Competing interests}

The authors declare that they have no competing interests.

Received: 25 May 2011 Accepted: 18 September 2011

Published: 18 September 2011

\section{References}

1. Fauci AS: The AIDS epidemic-considerations for the 21 st century. $N$ Engl J Med 1999, 341:1046-1050.

2. Palella FJ Jr, Delaney KM, Moorman AC, Loveless MO, Fuhrer J, Satten GA, Aschman DJ, Holmberg SD: Declining morbidity and mortality among patients with advanced human immunodeficiency virus infection. HIV Outpatient Study Investigators. N Engl J Med 1998, 338:853-860.

3. Vittinghoff E, Scheer S, O'Malley P, Colfax G, Holmberg SD, Buchbinder SP: Combination antiretroviral therapy and recent declines in AIDS incidence and mortality. J Infect Dis 1999, 179:717-720.

4. Bansi L, Smith C, Phillips A, Kirk S, Geretti AM, Johnson M, Mackie N, Post F, Gazzard B, Dunn D, Sabin C: The impact of HIV drug resistance testing on changes to treatment. AIDS 2011, 25:603-610.

5. Perno CF: The discovery and development of HIV therapy: the new challenges. Ann Ist Super Sanita 2011, 47:41-43.

6. Whaley KJ, Hanes J, Shattock R, Cone RA, Friend DR: Novel approaches to vaginal delivery and safety of microbicides: biopharmaceuticals, nanoparticles, and vaccines. Antiviral Res 2010, 88(Suppl 1):S55-S66.

7. Blais ME, Rowland-Jones S: Lessons from the failure of the adenovector HIV vaccine. F1000 Biol Rep 2009, 1:50.

8. Hessell AJ, Rakasz EG, Poignard P, Hangartner L, Landucci G, Forthal DN, Koff WC, Watkins DI, Burton DR: Broadly neutralizing human anti-HIV antibody $2 \mathrm{G} 12$ is effective in protection against mucosal SHIV challenge even at low serum neutralizing titers. PLOS Pathog 2009, 5:1000433.

9. Klasse P, Sanders R, Cerutti A, Moore J: How can HIV-1 Env immunogenicity be improved to facilitate antibody-based vaccine development? AIDS Res Hum Retroviruses 2011.

10. Lansdown AB: A pharmacological and toxicological profile of silver as an antimicrobial agent in medical devices. Adv Pharmacol Sci 2010, 2010:910686.

11. Lara HH, Ayala Nuñez NV, Ixtepan Turrent L, Rodriguez-Padilla C: Bactericidal effect of AgNPs against multidrug-resistant bacteria. Word Journal Microbiology Biotechnology 2010, 26:615-621.

12. Ayala Nuñez NV, Lara HH, Ixtepan Turrent L, Rodriquez-Padilla C: AgNPs Toxicity and Bactericidal Effect Against Methicillin-Resistant Staphylococcus aureus: Nanoscale Does Matter. Nanobiotechnology 2009, $5: 1-4$

13. Zuppa AA, D'Andrea V, Catenazzi P, Scorrano A, Romagnoli C: Ophthalmia neonatorum: what kind of prophylaxis? J Matern Fetal Neonatal Med 2011, 24:769-773.

14. Muangman P, Pundee C, Opasanon S, Muangman S: A prospective, randomized trial of silver containing hydrofiber dressing versus $1 \%$ silver sulfadiazine for the treatment of partial thickness burns. Int Wound J 2010, 7:271-276.

15. Vyas TK, Shah L, Amiji MM: Nanoparticulate drug carriers for delivery of HIV/AIDS therapy to viral reservoir sites. Expert Opin Drug Deliv 2006 3:613-628

16. Das NJ, Amiji MM, Bahia MF, Sarmento B: Nanotechnology-based systems for the treatment and prevention of HIV/AIDS. Adv Drug Deliv Rev 2010, 62:458-477. 
17. Sharma P, Garg S: Pure drug and polymer based nanotechnologies for the improved solubility, stability, bioavailability and targeting of anti-HIV drugs. Adv Drug Deliv Rev 2010, 62:491-502.

18. Mamo T, Moseman EA, Kolishetti N, Salvador-Morales C, Shi J, Kuritzkes DR Langer R, von AU, Farokhzad OC: Emerging nanotechnology approaches for HIV/AIDS treatment and prevention. Nanomedicine (Lond) 2010, 5:269-285.

19. Villalonga-Barber C, Micha-Screttas M, Steele BR, Georgopoulos A, Demetzos C: Dendrimers as biopharmaceuticals: synthesis and properties. Curr Top Med Chem 2008, 8:1294-1309.

20. Elechiguerra JL, Burt JL, Morones JR, Camacho-Bragado A, Gao X, Lara HH, Yacaman MJ: Interaction of AgNPs with HIV-1. J Nanobiotechnology 2005, 3:6.

21. Lara HH, Ayala-Nunez NV, Ixtepan-Turrent L, Rodriguez-Padilla C: Mode of antiviral action of AgNPs against HIV-1. J Nanobiotechnology 2010, 8:1.

22. Lara HH, Ixtepan-Turrent L, Garza-Trevino EN, Rodriguez-Padilla C: PVPcoated AgNPs block the transmission of cell-free and cell-associated HIV-1 in human cervical culture. J Nanobiotechnology 2010, 8:15.

23. Yuan W, Li X, Kasterka M, Gorny MK, Zolla-Pazner S, Sodroski J: Oligomerspecific conformations of the human immunodeficiency virus (HIV-1) gp41 envelope glycoprotein ectodomain recognized by human monoclonal antibodies. AIDS Res Hum Retroviruses 2009, 25:319-328.

24. Matsushita S, Robert-Guroff M, Rusche J, Koito A, Hattori T, Hoshino H, Javaherian K, Takatsuki K, Putney S: Characterization of a human immunodeficiency virus neutralizing monoclonal antibody and mapping of the neutralizing epitope. J Virol 1988, 62:2107-2114.

25. Putney SD, Matthews TJ, Robey WG, Lynn DL, Robert-Guroff M, Mueller WT, Langlois AJ, Ghrayeb J, Petteway SR Jr, Weinhold KJ: HTLV-III/LAVneutralizing antibodies to an E. coli-produced fragment of the virus envelope. Science 1986, 234:1392-1395.

26. Rusche $J R$, Lynn DL, Robert-Guroff M, Langlois AJ, Lyerly HK, Carson $H$, Krohn K, Ranki A, Gallo RC, Bolognesi DP: Humoral immune response to the entire human immunodeficiency virus envelope glycoprotein made in insect cells. Proc Natl Acad Sci USA 1987, 84:6924-6928.

27. Bell CH, Pantophlet R, Schiefner A, Cavacini LA, Stanfield RL, Burton DR, Wilson IA: Structure of antibody F425-B4e8 in complex with a V3 peptide reveals a new binding mode for HIV-1 neutralization. $J$ Mol Biol 2008, 375:969-978.

28. Diane V, Edouard T, Yassine AT, Francois R, Pierre-Alain R, Nicolas M, Vincent F, Karine B, Nicolas N, Philipe VDP, Jean-Pierre V: CD4+T cells spontaneously producing HIV-1 in breast milk from women with or without antiretroviral drugs. Retrovirology 2011, 8:34.

doi:10.1186/1477-3155-9-38

Cite this article as: Lara et al: Use of silver nanoparticles increased inhibition of cell-associated HIV-1 infection by neutralizing antibodies developed against HIV-1 envelope proteins. Journal of Nanobiotechnology 2011 9:38.

\section{Submit your next manuscript to BioMed Central and take full advantage of:}

- Convenient online submission

- Thorough peer review

- No space constraints or color figure charges

- Immediate publication on acceptance

- Inclusion in PubMed, CAS, Scopus and Google Scholar

- Research which is freely available for redistribution

Submit your manuscript at www.biomedcentral.com/submit 